\title{
Lidocaine increases the anti-inflammatory cytokine IL-10 following mechanical ventilation in healthy mice
}

\author{
S. van der Wal' ${ }^{1}$, M. Vaneker' ${ }^{1}$, M. Steegers' ${ }^{1}$ B. van Berkum¹, M. Kox², J. van der Laak ${ }^{3}$, J. van der Hoeven², \\ K. Vissers ${ }^{1}$ and G. J. Scheffer ${ }^{1}$ \\ 'Department of Anesthesiology, Pain and Palliative Care, Radboud University Nijmegen Medical Center, Nijmegen, The Netherlands \\ ${ }^{2}$ Department of Intensive Care Medicine, Radboud University Nijmegen Medical Center, Nijmegen, The Netherlands \\ ${ }^{3}$ Department of Pathology, Radboud University Nijmegen Medical Center, Nijmegen, The Netherlands
}

\begin{abstract}
Correspondence
S. van der Wal, Department of Anesthesiology,

Pain and Palliative Care, Radboud University

Nijmegen Medical Center, P.O. Box 9101, 6525

GA Nijmegen,

The Netherlands

E-mail: s.vanderwal@anes.umcn.nl

Conflicts of interest

There are no conflicts in interest.

\section{Funding}

No funding received.

Submitted 27 August 2014; accepted 28 August 2014; submission 6 May 2014.

\section{Citation}

van der Wal S, Vaneker M, Steegers M, van Berkum B, Kox M, van der Laak J, van der Hoeven J, Vissers K, Scheffer GJ. Lidocaine increases the anti-inflammatory cytokine IL-10 following mechanical ventilation in healthy mice. Acta Anaesthesiologica Scandinavica 2014
\end{abstract}

doi: 10.1111/aas.12417
Background: Mechanical ventilation (MV) induces an inflammatory response that may result in (acute) lung injury. Lidocaine, an amide local anesthetic, has anti-inflammatory properties in vitro and in vivo, possibly due to an attenuation of pro-inflammatory cytokines, intracellular adhesion molecule-1 (ICAM-1), and reduction of neutrophils influx. We hypothesized an attenuation of MV-induced inflammatory response with intravenously administered lidocaine. Methods: Lidocaine (Lido) (2, 4, and $8 \mathrm{mg} / \mathrm{kg} / \mathrm{h}$ ) was intravenously administered during $4 \mathrm{~h}$ of $\mathrm{MV}$ with a tidal volume of $8 \mathrm{ml} /$ $\mathrm{kg}$, positive end expiratory pressure $1,5 \mathrm{cmH}_{2} \mathrm{O}$ and $\mathrm{FiO}_{2} 0.4$. We used one ventilated control (CON) group receiving vehicle. After MV, mice were euthanized, and lungs and blood were immediately harvested, and cytokine levels and ICAM-1 levels were measured in plasma and lung homogenates. Pulmonary neutrophils influx was determined in LEDER-stained slices of lungs. Anesthetic need was determined by painful hind paw stimulation.

Results: Lidocaine-treated animals (Lido 2, 4 and $8 \mathrm{mg} / \mathrm{kg} / \mathrm{h}$ ) showed higher interleukin (IL)-10 plasma levels compared to control animals. Lidocaine treatment with $8 \mathrm{mg} / \mathrm{kg} / \mathrm{h}$ (Lido 8) resulted in higher IL-10 in lung homogenates. No differences were observed in pro-inflammatory cytokines, ICAM-1, and pulmonary influx between the different ventilated groups.

Conclusions: Intravenously administered lidocaine increases levels of plasma IL- 10 with infusion from 2,4 , and $8 \mathrm{mg} / \mathrm{kg} / \mathrm{h}$ and pulmonary levels of IL- 10 with $8 \mathrm{mg} / \mathrm{kg} / \mathrm{h}$ in a murine mechanical ventilation model. Intravenously administered lidocaine appears to reduce anesthetic need in mice.
For patients with acute respiratory failure, mechanical ventilation (MV) can be life saving. However, a large body of evidence suggests that MV can result in lung injury, so-called ventilatorinduced lung injury. ${ }^{1,2}$ It is widely assumed that an inflammatory response, characterized by release of inflammatory cytokines and influx of immune cells such as neutrophils contributes to the development of lung injury. ${ }^{2-4}$ To date, no effective therapy exists to attenuate the MV-induced inflammatory response.

Lidocaine is an amide local anesthetic and a nonspecific sodium channel blocker that is mostly used for the treatment of acute and chronic pain. It 
was demonstrated that low-dose intravenous lidocaine acts as an anti-hyperalgesic and antiinflammatory agent. ${ }^{5,6}$ Extensive in vitro research showed that lidocaine attenuates priming of human neutrophils by inhibition of G-protein coupled receptors. ${ }^{7,8}$ Furthermore, lidocaine attenuated activated endothelial interleukin (IL)-1, 6, and 8 concentrations and intracellular adhesion molecule-1 (ICAM-1), important for transport of immune cells to site of inflammation. ${ }^{9,10}$ In different in vivo models, intravenous lidocaine reduced levels of tumor necrosis factor (TNF)- $\alpha$, IL-1 $\beta$, IL-6, and Il-8. ${ }^{11-13}$ Also, systemic lidocaine was found to attenuate acute lung injury in rabbits. ${ }^{14,15}$ An additional effect of lidocaine infusion is that the requirements for anesthetics are diminished. ${ }^{16,17}$ In human research, an attenuation in inflammatory response (measured by IL-6, IL-8, and an IL-1 receptor antagonist) in plasma has been found at the end of abdominal surgery in response to lidocaine. ${ }^{18-20}$

Since lidocaine seems to have prominent antiinflammatory effects, we aim to investigate the role of intravenously administered lidocaine at different dosages of $2 \mathrm{mg} / \mathrm{kg} / \mathrm{h}, 4 \mathrm{mg} / \mathrm{kg} / \mathrm{h}$, and $8 \mathrm{mg} / \mathrm{kg} / \mathrm{h}$ during $4 \mathrm{~h}$ of mechanical ventilation in healthy mice in an established acute phase model. ${ }^{21-23}$

We hypothesize that intravenously administered lidocaine attenuates the inflammatory response following MV.

\section{Methods}

All experiments were approved by the Regional Animal Ethics Committee in Nijmegen and performed under the guidelines of the Dutch Council for Animal Care and The National Institutes of Health.

\section{Animals}

All studies were performed in C57BL6 male mice in our established MV mice model. ${ }^{21-23}$ Mice were housed in a light and temperature controlled room under specific pathogen-free conditions. Standard pelleted chow $(1.00 \% \mathrm{Ca} ; 0.22 \% \mathrm{Mg}$; $0.24 \% \mathrm{Na} ; 0.70 \% \mathrm{P} ; 1.02 \% \mathrm{~K}$; SSNIFF Spezialdiäten $\mathrm{GmbH}$, Soest, Germany) and drinking water were available ad libitum.

\section{Experimental design}

Four groups of mice ( $n=8$ /group, randomly allocated) were studied after MV: control mice with vehicle (CON) and three groups of mice treated with different doses of lidocaine $2 \%$ (Lido) (Fresenius Kabi, Zeist, the Netherlands), $2 \mathrm{mg} / \mathrm{kg} / \mathrm{h}$ (Lido 2), $4 \mathrm{mg} / \mathrm{kg} / \mathrm{h}$ (Lido 4), and $8 \mathrm{mg} / \mathrm{kg} / \mathrm{h}$ (Lido 8). Lidocaine was administered intravenously via an indwelling intravenous tail catheter just before MV and continued during $4 \mathrm{~h}$. The control group $(\mathrm{CON})$ received an equal volume of $\mathrm{NaCl} \quad 0.9 \%$ intravenously. Intra-arterial carotid blood pressure and heart rhythm was measured throughout the experiment. Arterial blood gas analysis (iSTAT, Abbott, Birmingham, United Kingdom) was performed after $4 \mathrm{~h}$ of MV (data not shown).

Lipopolysaccharide (LPS) was measured in the ventilation circuit by Limulus Amebocyte Lysate testing (Cambrex Bio Science, Walkersville, MD; detection limit: $0.06 \mathrm{IU} / \mathrm{ml}$ ) to rule out contamination with LPS in our experimental setting. No LPS could be detected in air, tubing, or ventilator.

\section{Mechanical ventilation and anesthetic need}

Mice were anesthetized with an intraperitoneal injection of a combination of ketamine, medetomidine, and atropine (KMA): $7.5 \mu \mathrm{l}$ per gram of body weight of induction KMA mix (consisting of $1.26 \mathrm{ml}$ ketamine, $100 \mathrm{mg} / \mathrm{ml} ; 0.2 \mathrm{ml}$ medetomidine, $1 \mathrm{mg} / \mathrm{ml} ; 1 \mathrm{ml}$ atropine, $0.5 \mathrm{mg} / \mathrm{ml}$; and $5 \mathrm{ml} \mathrm{NaCl}, 0.9 \%$ ). Animals were orally intubated and mechanically ventilated (MiniVent, Hugo Sachs Elektronik-Harvard apparatus, MarchHugstetten, Germany) for $4 \mathrm{~h}$. The following MV settings were used: tidal volume $8 \mathrm{ml} / \mathrm{kg}$ and frequency $170 / \min , 1,5 \mathrm{~cm} \mathrm{H}_{2} \mathrm{O}$ positive endexpiratory pressure and fraction of inspired oxygen was set to 0.4 . These settings are within the normal range of tidal volume, and respiratory rate measured during spontaneous ventilation in C57BL6 mice. ${ }^{24}$

To maintain anesthesia, $5.0 \mu \mathrm{l}$ per gram of body weight boluses of maintenance KMA mix (consisting of $0.72 \mathrm{ml}$ ketamine, $100 \mathrm{mg} / \mathrm{ml} ; 0.08 \mathrm{ml}$ medetomidine, $1 \mathrm{mg} / \mathrm{ml} ; 0.3 \mathrm{ml}$ atropine, $0.5 \mathrm{mg}$ / $\mathrm{ml}$; and $18.9 \mathrm{ml} \mathrm{NaCl}, 0.9 \%$ ) was administered when showed a positive reaction after manually 
administered painful hind paw stimulation via an intraperitoneally placed catheter. Painful hind paw stimulation was performed every $30 \mathrm{~min}$ and represented anesthetic need. Rectal temperature was monitored continuously and maintained between $36.0^{\circ} \mathrm{C}$ and $37.5^{\circ} \mathrm{C}$ using a heating pad.

\section{Tissue harvesting}

Blood was collected by exsanguination, centrifuged ( $5 \mathrm{~min}, 14,000 \mathrm{rpm}$ ), and plasma was stored at $-80^{\circ} \mathrm{C}$ for cytokine analysis. Immediately after exsanguination, heart and lungs were carefully removed en block via midline sternotomy. The right upper and lower lobes were snap frozen in liquid nitrogen and stored at $-80^{\circ} \mathrm{C}$. The left lobes were snap frozen and placed in $500 \mu l$ lysis buffer containing phosphate buffered saline, $0.5 \%$ triton $\mathrm{X}-100$, and protease inhibitor (complete EDTAfree tablets, Roche, Woerden, the Netherlands). Subsequently, the left lobes were homogenized using a polytron and subjected to two rapid freezethaw cycles using liquid nitrogen. Finally, homogenates were centrifuged ( $10 \mathrm{~min}, 14,000$ r.p.m., $4^{\circ} \mathrm{C}$ ), and the supernatant was stored at $-80^{\circ} \mathrm{C}$ until cytokine analysis.

\section{Cytokine analysis}

A simultaneous Luminex assay was used to determine plasma cytokine levels of TNF- $\alpha$, IL-6, IL-10, keratinocyte-derived chemokine (KC), and IL-1 $\beta$ (Milliplex, Millipore, Billerica, MA, USA).

TNF- $\alpha$, IL-6, and KC (murine equivalent of human IL-8) in lung homogenate were determined by enzyme-linked-immunosorbent assay (ELISA) (for IL-6 and IL10; CytoSet, BioSource, CA, USA; for TNF- $\alpha$ and KC; ELISA-Kit, RED Systems, Minneapolis, MN, USA). Lower detection limits: IL- $1 \alpha$ and IL- $1 \beta 40 \mathrm{pg} / \mathrm{ml}$; TNF- $\alpha$ : $32 \mathrm{pg} / \mathrm{ml}$; IL-6: $160 \mathrm{pg} / \mathrm{ml} ; \mathrm{IL}-10: 16 \mathrm{pg} / \mathrm{ml}$ and KC: $160 \mathrm{pg} / \mathrm{ml}$.

IL- $1 \beta$ and IL- $1 \alpha$ in lung homogenate were determined using a radioimmunoassay as described previously. ${ }^{23}$ Total protein concentrations in the lung homogenates were determined using a bicinchoninic acid assay (Thermo Fisher Scientific, Etten-Leur, the Netherlands). Cytokine concentrations in the homogenates were normalized for protein concentration.

\section{ICAM-1 analysis}

Concentration of mouse sICAM-1 was determined in plasma and lung tissue using the quantikine mouse sICAM (CD54) ELISA (MIC100) kit (R \& D systems, Abingdon, United Kingdom). Lower detection limits: $24,8 \mathrm{ng} / \mathrm{ml}$.

\section{Pulmonary neutrophil influx}

After overnight incubation in $4 \%$ buffered formalin solution, the right middle lung lobe was dehydrated and embedded in paraplast (Amstelstad, Amsterdam, the Netherlands). Sections of $4-\mu \mathrm{m}$ thickness were used. Enzyme histochemistry using chloracetatesterase (LEDER staining) was used to visualize the enzyme activity in the neutrophils. Neutrophils were counted manually (10 fields per mouse, blinded), and after automated correction for air/tissue ratio, the average number of neutrophils $/ \mu \mathrm{m}^{2}$ per mouse was calculated. ${ }^{23}$

\section{Statistical analysis}

We performed a sample size calculation based on previous investigations considering a difference of $40 \%$ in cytokine levels between ventilated and control mice with a type 1 error of $5 \%(\alpha=0.05)$ and a power of $80 \%(\beta=0.2) .{ }^{21-23}$ This resulted in a group size of eight animals per group.

Shapiro-Wilk tests showed that data were not normally or log normally distributed.

Data are therefore expressed as median with interquartile range and depicted as column bar graphs. Differences between controls vs. lidocaine groups were studied using Mann-Whitney tests. Statistical analysis was performed using Graphpad Prism 5 software (Graphpad Software, La Jolla, CA, USA). $P$-values $<0.05$ were considered significant.

\section{Results}

\section{Cardiopulmonary physiology}

All mice in this experiment exhibited stable hemodynamic variables during MV $(P>0.05)$.

Mean arterial pressure was within normal limits and remained above $65 \mathrm{mmHg}$ (except in one mouse measured in the Lido 8 group), which was in line with previous data from our lab in this 
model. ${ }^{21-23}$ We did not observe arrhythmic changes in the different MV groups (except one mouse measured in the Lido 8 group). Blood gas values remained within normal range after $4 \mathrm{~h}$ of $M V$, and no differences were observed within the ventilated groups (data not shown). Four mice, one in each group, died during the experiment ( $n=7$ in each group remaining). Two mice died during instrumentation (CON, Lido 2, no measurement on hemodynamics obtained yet), one mouse died in its cage before the experiment started without apparent reason (Lido 4). One mouse died before the end of the experiment (Lido 8) from severe hypotension and bradycardia resulting in death.

\section{Cytokine analysis in plasma}

Cytokine analysis in plasma revealed no significant differences between the ventilated groups in IL-1 $\beta$, IL-6, TNF- $\alpha$, and KC. However, IL-10 analysis showed a significant increase in all the lidocaine groups, 2, 4, and $8 \mathrm{mg} / \mathrm{kg} / \mathrm{h}$ (Lido 2 , Lido 4, and Lido 8) in comparison with the control group (CON) (Fig. 1).

\section{Cytokine analysis in lungs}

IL-10 analysis showed a significant increase between the control group (CON) in comparison with the lidocaine $8 \mathrm{mg} / \mathrm{kg} / \mathrm{h}$ group (Lido 8 ) but not in comparison with the lidocaine $2 \mathrm{mg} / \mathrm{kg} / \mathrm{h}$ and $4 \mathrm{mg} / \mathrm{kg} / \mathrm{h}$ group (Fig. 2).

Cytokine analysis in lung homogenates revealed no significant differences between the different ventilated groups in IL-1 $\beta$, IL-6, TNF- $\alpha$, $\mathrm{KC}$, and IL- $1 \alpha$.

\section{ICAM-1 analysis}

ICAM-1 analysis in plasma and lung homogenates showed no significant differences between the different ventilated groups (Fig. 3).

\section{Pulmonary neutrophil influx}

No significant differences between pulmonary neutrophil influx measured per $\mu \mathrm{m}^{2}$ were observed between the different ventilated groups (Fig. 4).

\section{Anesthetic need}

Mice showed a decrease in anesthetic need in lidocaine $2 \mathrm{mg} / \mathrm{kg} / \mathrm{h}$ and lidocaine $8 \mathrm{mg} / \mathrm{kg} / \mathrm{h}$ (lido 2 and 8) group, compared with control mice (CON) (Fig. 5).

\section{Discussion}

This study is the first to show that intravenously administered lidocaine caused an increase in pulmonary and systemic IL-10 levels following MV in healthy mice compared to control animals.

IL-10 is a well-known anti-inflammatory cytokine which limits the immune response during infections and is produced by nearly every type of cell in the immune system. ${ }^{25,26}$ IL-10 is known to decrease the synthesis of pro-inflammatory cytokines in acute phase response as IL- $1 \alpha$, IL- $1 \beta$, IL-6, and TNF- $\alpha$ by neutrophils. ${ }^{27}$ In mouse lung fibroblast exposed to mechanical stretch, IL-10 inhibited inflammatory cytokines. ${ }^{25}$ Low lung concentrations of IL-10 in patients with acute lung injury is an indication for development of adult respiratory distress syndrome. ${ }^{28}$ Administration of IL-10 has shown protective effects in LPS-induced lung injury. ${ }^{29}$ Interestingly, inhaled IL-10 attenuates biotrauma and mortality in a ventilator-induced lung injury model in rats. ${ }^{30}$

We did not observe an attenuation of proinflammatory cytokine levels, pulmonary ICAM-1 levels, or pulmonary neutrophil influx. A possible explanation for this could be that although IL-10 is known to attenuate inflammation, the acute phase response in our MV model is only a mild inflammatory response.

We did not include an unventilated group, whereas the placement of an indwelling tail catheter in an awake mouse provides extreme stress which could lead to false high cytokine levels. Furthermore, previous investigations have shown that cytokine levels of unventilated mice are below or extremely close to detection limits. ${ }^{21-23}$ Dosage of lidocaine, especially $8 \mathrm{mg} / \mathrm{kg} / \mathrm{h}$, is relatively high. In comparison, dosages of $2 \mathrm{mg} / \mathrm{kg} / \mathrm{h}$ can be considered safe in humans, $4 \mathrm{mg} / \mathrm{kg} / \mathrm{h}$ is relatively high, and $8 \mathrm{mg} / \mathrm{kg} / \mathrm{h}$ is considered too high in humans. ${ }^{31}$ Previous research has shown an ED50 for central nervous system and cardiac toxicity in mice of approximately $19.5 \mathrm{mg} / \mathrm{kg}$ and 
A

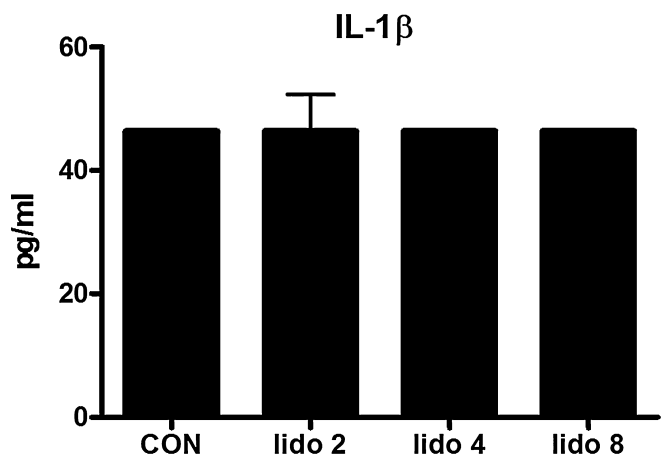

C

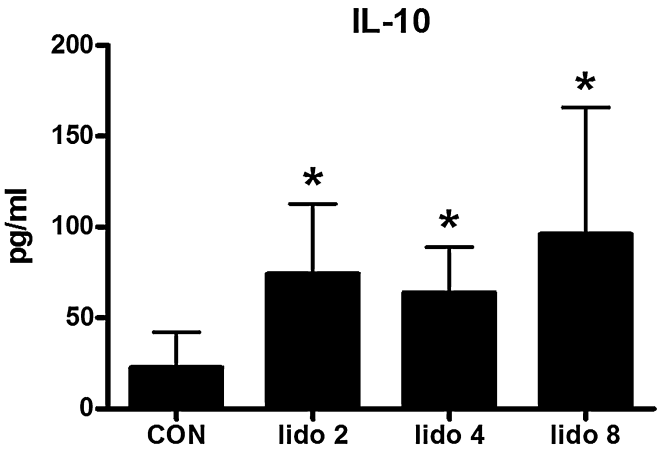

B

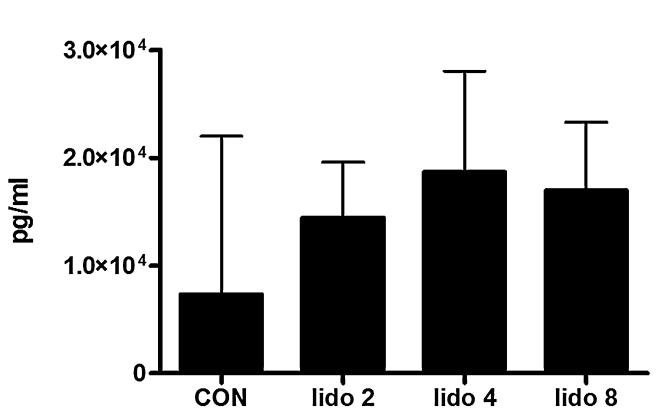

D

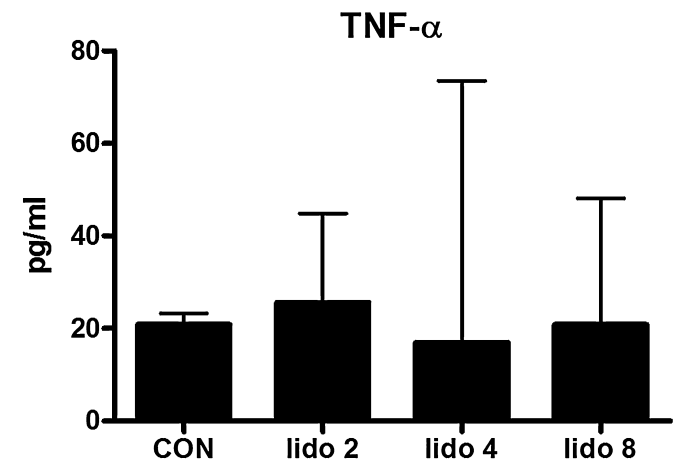

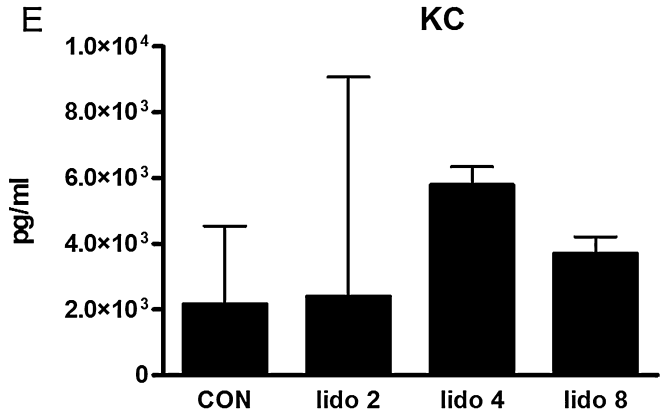

Fig. 1. Cytokine levels in plasma. Levels of interleukin (IL)-1 $1 \beta, \mathrm{IL}-6, \mathrm{IL}-10$, tumor necrosis factor (TNF)- $\alpha$, and keratinocyte derived chemokine (KC) in ventilated control (CON) compared with ventilated lidocaine mice (Lido) receiving lidocaine in different dosages. Lidocaine was given in dosages of $2 \mathrm{mg} / \mathrm{kg} / \mathrm{h}, 4 \mathrm{mg} / \mathrm{kg} / \mathrm{h}$, and $8 \mathrm{mg} / \mathrm{kg} / \mathrm{h}$. (Panels A-E). Lido 2,4, and 8 showed increased IL-10 compared with CON. No differences were observed within the different ventilated groups of IL-1 $\beta$, IL-6, IL-10, TNF- $\alpha$, and KC. Data are expressed as median with interquartile range (IQR). ( $* P<0.05)$

$21.2 \mathrm{mg} / \mathrm{kg} .{ }^{32}$ The cardiac side effects of lidocaine, contributed by the blockage of voltage-gated sodium channels, appear at plasma levels higher than $10 \mu \mathrm{g} / \mathrm{ml}$ in humans. ${ }^{33}$ Considering the high ED50 for lidocaine in mice and extensive animal research in lidocaine toxicity with similar dosage, we did not measure plasma levels of lidocaine, and we have strong indications we stayed under critical plasma levels of lidocaine. One mouse however died in the $8 \mathrm{mg} / \mathrm{kg} / \mathrm{h}$ group, because of uncontrollable hypotension, which could possi- bly indicate an overdose of lidocaine. In lung homogenates, a significant increase of IL-10 was observed only at $8 \mathrm{mg} / \mathrm{kg} / \mathrm{h}$ lidocaine (Lido 8 ), suggesting a possible dose-related effect. Mice in our experiment showed a decrease in anesthetic need with lidocaine administration which is consistent with previous experiments. ${ }^{16,17}$ Although a decreased anesthetic need did not lead to an attenuation of other cytokine levels in our experiment, an influence on the level of IL-10 cannot completely be ruled out. 

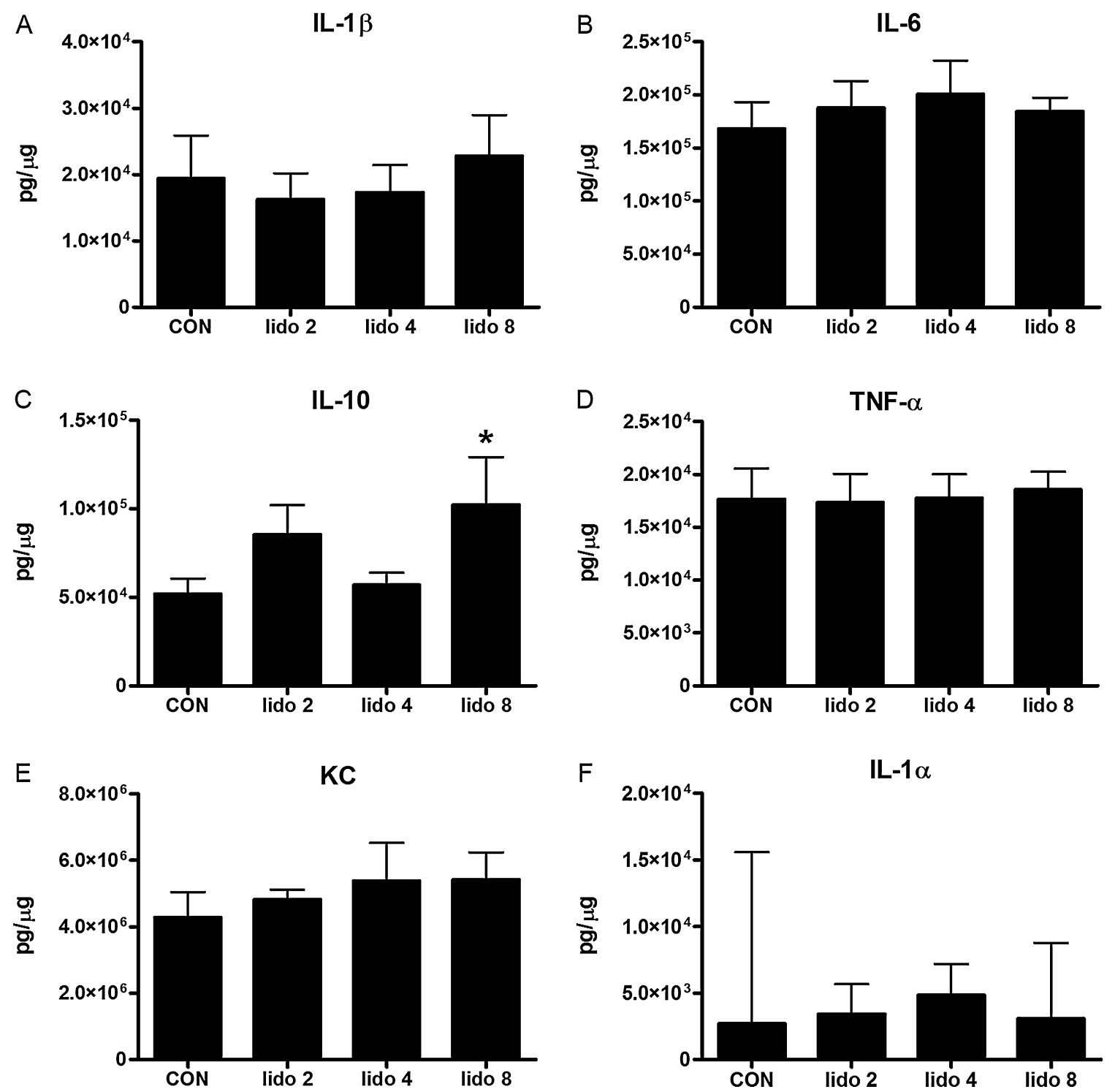

Fig. 2. Cytokine levels in lung homogenates. Levels of interleukin (IL)-1 $\beta$, IL-6, IL-10, tumor necrosis factor (TNF)- $\alpha$, keratinocyte derived chemokine $(\mathrm{KC})$, and IL-1 $\alpha$ in ventilated control (CON) compared with ventilated lidocaine mice (Lido) receiving lidocaine in different dosages. Lidocaine was given in dosages of $2 \mathrm{mg} / \mathrm{kg} / \mathrm{h}, 4 \mathrm{mg} / \mathrm{kg} / \mathrm{h}$, and $8 \mathrm{mg} / \mathrm{kg} / \mathrm{h}$. (Panels A-F). Lido 8 showed increased IL-10 compared with CON. No differences were observed within the different ventilated groups of IL-1 $\beta$, IL-6, IL-10, TNF- $\alpha, \mathrm{KC}$, and IL-1 $\alpha$. Data are expressed as median with interquartile range (IQR). $\left({ }^{*}>0.05\right)$

In conclusion, low-dose intravenously administered lidocaine in MV increases levels of plasma IL-10 with infusion from $2 \mathrm{mg} / \mathrm{kg} / \mathrm{h}$, $4 \mathrm{mg} / \mathrm{kg} / \mathrm{h}$, and $8 \mathrm{mg} / \mathrm{kg} / \mathrm{h}$ and pulmonary levels of IL-10 with $8 \mathrm{mg} / \mathrm{kg} / \mathrm{h}$, in a murine mechanical ventilation model indicating a modulatory role of lidocaine in inflammatory response. After $4 \mathrm{~h}$ of $\mathrm{MV}$, no effects were found on pro-inflammatory cytokines, neutrophil influx, or ICAM-1 levels.
More research has to be performed to elucidate the exact role of lidocaine in ventilator-induced pulmonary inflammation and cytokine levels during time, and since we only ventilated mice for $4 \mathrm{~h}$, the full impact of lidocaine on the MV-induced inflammatory response, cannot be fully described.

Lidocaine could prove to be an interesting therapeutic in multiple hit models. Furthermore, 
A

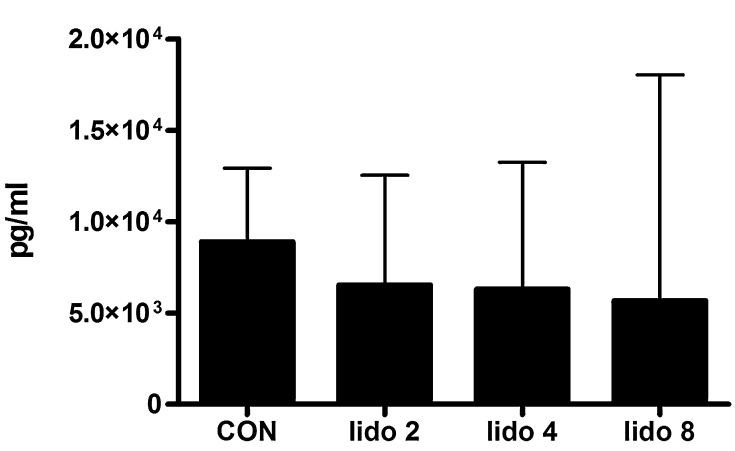

B

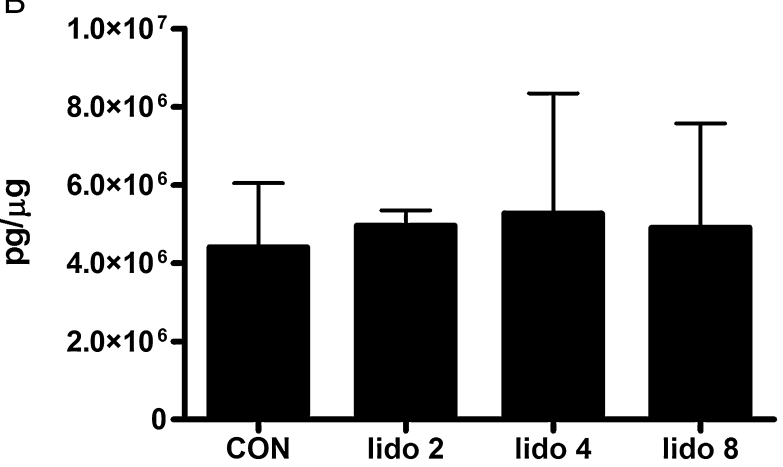

Fig. 3. Intracellular adhesion molecule (ICAM)-1 levels in plasma (Panel A) and lung homogenates (Panel B). Levels of in ventilated control (CON) compared with ventilated lidocaine mice (Lido) receiving lidocaine in different dosages. Lidocaine was given in dosages of $2 \mathrm{mg} / \mathrm{kg} / \mathrm{h}$, $4 \mathrm{mg} / \mathrm{kg} / \mathrm{h}$, and $8 \mathrm{mg} / \mathrm{kg} / \mathrm{h}$. No differences of ICAM-1 were observed between the different ventilated groups. Data are expressed as median with interquartile range (IQR).

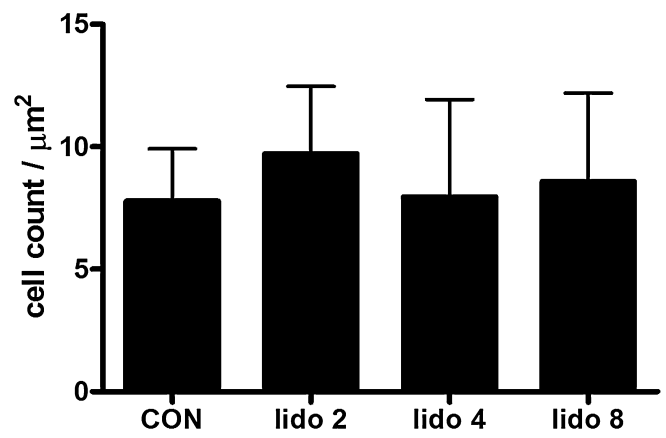

Fig. 4. Pulmonary neutrophils influx in lung. Neutrophil influx was measured by cell count in ventilated control (CON) compared with ventilated lidocaine mice (Lido) receiving lidocaine in different dosages. Lidocaine was given in dosages of $2 \mathrm{mg} / \mathrm{kg} / \mathrm{h}, 4 \mathrm{mg} / \mathrm{kg} / \mathrm{h}$, and $8 \mathrm{mg} / \mathrm{kg} / \mathrm{h}$. No differences were observed between the different ventilated groups. Data are expressed as median with interquartile range (IQR).

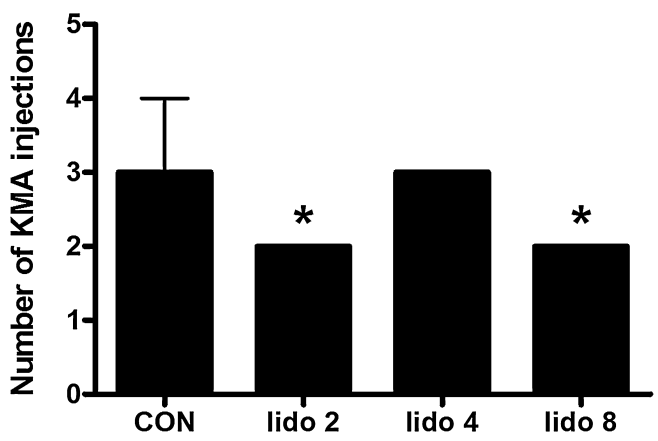

Fig. 5. Anesthetic need in mice. Anesthetic need was determined by painful hind paw stimulation every $30 \mathrm{~min}$. If the mouse retracted his hind paw, $5.0 \mu \mathrm{l}$ per gram of body weight boluses of maintenance ketamine, medetomidine, and atropine (KMA) mix (consisting of $0.72 \mathrm{ml}$ ketamine, $100 \mathrm{mg} / \mathrm{ml} ; 0.08 \mathrm{ml}$ medetomidine, $1 \mathrm{mg} / \mathrm{ml} ; 0.3 \mathrm{ml}$ atropine, $0.5 \mathrm{mg} / \mathrm{ml}$; and $18.9 \mathrm{ml} \mathrm{NaCl}, 0.9 \%$ ) was administered. The number of KMA injections was measured in the different ventilated groups receiving lidocaine in dosages of $2 \mathrm{mg} / \mathrm{kg} / \mathrm{h}, 4 \mathrm{mg} / \mathrm{kg} / \mathrm{h}$, and $8 \mathrm{mg} / \mathrm{kg} / \mathrm{h}$. (Lido 2, 4, and 8) compared with ventilated control (CON). Differences were observed between CON compared with Lido 2 and Lido 8. Data are expressed as median with interquartile range (IQR). $\left({ }^{\star} P<0.05\right)$

intravenously administered lidocaine decreases anesthetic need.

\section{References}

1. Gajic O, Dara SI, Mendez JL, Adesanya AO, Festic E, Caples SM, Rana R, St Sauver JL, Lymp JF, Afessa B, Hubmayr RD.

Ventilator-associated lung injury in patients without acute lung injury at the onset of mechanical ventilation. Crit Care Med 2004; 32: 1817-24.

2. Ranieri VM, Giunta F, Suter PM, Slutsky AS. Mechanical ventilation as a mediator of multisystem organ failure in acute respiratory distress syndrome. JAMA 2000; 284: 43-4.

3. Dolinay T, Kim YS, Howrylak J, Hunninghake GM, An CH, Fredenburgh L, Massaro AF, Rogers A, Gazourian L, Nakahira K, Haspel JA, Landazury R, Eppanapally $\mathrm{S}$,

Christie JD, Meyer NJ, Ware LB, Christiani DC, Ryter SW, Baron RM, Choi AM.

Inflammasome-regulated cytokines are critical mediators of acute lung injury. Am J Respir Crit Care Med 2012; 185: 1225-34.

4. Matzinger P. The danger model: a renewed sense of self. Science 2002; 296: 301-5.

5. Hollmann MW, Durieux ME. Local anesthetics and the inflammatory response: a new therapeutic indication? Anesthesiology 2000; 93: 858-75. 
6. Koppert W, Ostermeier N, Sittl R, Weidner C, Schmelz M. Low-dose lidocaine reduces secondary hyperalgesia by a central mode of action. Pain 2000; 85: 217-24.

7. Fischer LG, Bremer M, Coleman EJ, Conrad B, Krumm B, Gross A, Hollmann MW, Mandell G, Durieux ME. Local anesthetics attenuate lysophosphatidic acid-induced priming in human neutrophils. Anesth Analg 2001; 92: 1041-7.

8. Hollmann MW, Gross A, Jelacin N, Durieux ME. Local anesthetic effects on priming and activation of human neutrophils. Anesthesiology 2001; 95: 113-22.

9. Lan W, Harmon DC, Wang JH, Shorten GD, Redmond $\mathrm{PH}$. Activated endothelial interleukin-1beta, -6 , and -8 concentrations and intercellular adhesion molecule-1 expression are attenuated by lidocaine. Anesth Analg 2005; 100: 409-12.

10. Lan W, Harmon D, Wang JH, Shorten G, Redmond P. The effect of lidocaine on neutrophil CD11b/CD18 and endothelial ICAM-1 expression and IL-1beta concentrations induced by hypoxia-reoxygenation. Eur J Anaesthesiol 2004; 21: 967-72.

11. Peiro JR, Barnabe PA, Cadioli FA, Cunha FQ, Lima VM, Mendonca VH, Santana AE, Malheiros EB, Perri SH, Valadao CA. Effects of lidocaine infusion during experimental endotoxemia in horses. J Vet Intern Med 2010; 24: 940-8.

12. Flondor M, Listle H, Kemming GI, Zwissler B, Hofstetter C. Effect of inhaled and intravenous lidocaine on inflammatory reaction in endotoxaemic rats. Eur J Anaesthesiol 2010; 27: 53-60.

13. Taniguchi T, Shibata K, Yamamoto K, Mizukoshi Y, Kobayashi T. Effects of lidocaine administration on hemodynamics and cytokine responses to endotoxemia in rabbits. Crit Care Med 2000; 28: 755-9.

14. Nishina K, Mikawa K, Maekawa N, Takao Y, Obara H. Does early posttreatment with lidocaine attenuate endotoxin-induced acute injury in rabbits? Anesthesiology 1995; 83: 169-77.

15. Kiyonari Y, Nishina K, Mikawa K, Maekawa N, Obara $\mathrm{H}$. Lidocaine attenuates acute lung injury induced by a combination of phospholipase A2 and trypsin. Crit Care Med 2000; 28: 484-9.

16. Rezende $\mathrm{ML}$, Wagner AE, Mama KR, Ferreira TH, Steffey EP. Effects of intravenous administration of lidocaine on the minimum alveolar concentration of sevoflurane in horses. Am J Vet Res 2011; 72: 446-51.

17. Matsubara LM, Oliva VN, Gabas DT, Oliveira GC, Cassetari ML. Effect of lidocaine on the minimum alveolar concentration of sevoflurane in dogs. Vet Anaesth Analg 2009; 36: 407-13.

18. Kuo CP, Jao SW, Chen KM, Wong CS, Yeh CC, Sheen MJ, Wu CT. Comparison of the effects of thoracic epidural analgesia and i.v. infusion with lidocaine on cytokine response, postoperative pain and bowel function in patients undergoing colonic surgery. Brit J Anaesth 2006; 97: 640-6.

19. Herroeder S, Pecher S, Schonherr ME, Kaulitz G, Hahnenkamp K, Friess H, Bottiger BW, Bauer H, Dijkgraaf MG, Durieux ME, Hollmann MW. Systemic lidocaine shortens length of hospital stay after colorectal surgery: a double-blinded, randomized, placebo-controlled trial. Ann Surg 2007; 246: 192-200.

20. Yardeni IZ, Beilin B, Mayburd E, Levinson Y, Bessler $\mathrm{H}$. The effect of perioperative intravenous lidocaine on postoperative pain and immune function. Anesth Analg 2009; 109: 1464-9.

21. Vaneker M, Halbertsma FJ, van Egmond J, Netea MG, Dijkman HB, Snijdelaar DG, Joosten LA, van der Hoeven JG, Scheffer GJ. Mechanical ventilation in healthy mice induces reversible pulmonary and systemic cytokine elevation with preserved alveolar integrity: an in vivo model using clinical relevant ventilation settings. Anesthesiology 2007; 107: 419-26.

22. Vaneker M, Heunks LM, Joosten LA, van Hees HW, Snijdelaar DG, Halbertsma FJ, van Egmond J, Netea MG, van der Hoeven JG, Scheffer GJ. Mechanical ventilation induces a toll/interleukin-1 receptor domain-containing adapter-inducing interferon beta-dependent inflammatory response in healthy mice. Anesthesiology 2009; 111: 836-43.

23. Vaneker M, Joosten LA, Heunks LM, Snijdelaar DG, Halbertsma FJ, van Egmond J, Netea MG, van der Hoeven JG, Scheffer GJ. Low-tidal-volume mechanical ventilation induces a toll-like receptor 4-dependent inflammatory response in healthy mice. Anesthesiology 2008; 109: 465-72.

24. Janssen BJ, Smits JF. Autonomic control of blood pressure in mice: basic physiology and effects of genetic modification. Am J Physiol Regul Integr Comp Physiol 2002; 282: R1545-64. 
25. Hawwa RL, Hokenson MA, Wang Y, Huang Z, Sharma S, Sanchez-Esteban J. IL-10 inhibits inflammatory cytokines released by fetal mouse lung fibroblasts exposed to mechanical stretch. Pediatr Pulmonol 2011; 46: 640-9.

26. Banchereau J, Pascual V, O'Garra A. From IL-2 to IL-37: the expanding spectrum of anti-inflammatory cytokines. Nat Immunol 2012; 13: 925-31.

27. Koj A. Termination of acute-phase response: role of some cytokines and anti-inflammatory drugs. Gen Pharmacol 1998; 31: 9-18.

28. Donnelly SC, Strieter RM, Reid PT, Kunkel SL, Burdick MD, Armstrong I, Mackenzie A, Haslett C. The association between mortality rates and decreased concentrations of interleukin-10 and interleukin-1 receptor antagonist in the lung fluids of patients with the adult respiratory distress syndrome. Ann Intern Med 1996; 125: 191-6.
29. Inoue G. Effect of interleukin-10 (IL-10) on experimental LPS-induced acute lung injury. J Infect Chemother 2000; 6: 51-60.

30. Hoegl S, Boost KA, Czerwonka H, Dolfen A, Scheiermann P, Muhl H, Zwissler B, Hofstetter C. Inhaled IL-10 reduces biotrauma and mortality in a model of ventilator-induced lung injury. Respir Med 2009; 103: 463-70.

31. McCarthy GC, Megalla SA, Habib AS. Impact of intravenous lidocaine infusion on postoperative analgesia and recovery from surgery: a systematic review of randomized controlled trials. Drugs 2010; 70: 1149-63.

32. Cheung HM, Lee SM, MacLeod BA, Ries CR, Schwarz SK. A comparison of the systemic toxicity of lidocaine versus its quaternary derivative QX-314 in mice. Can J Anaesth 2011; 58: 443-50.

33. Mehra P, Caiazzo A, Maloney P. Lidocaine toxicity. Anesth Prog 1998; 45: 38-41. 